\section{Locum consultants}

The College continues to receive reports of a national shortage of suitably qualified psychiatrists able to carry out locum consultant work.

It has been agreed that the College will forward, to relevant College Regional Advisers, the names of those consultant psychiatrists who have recently retired and who have contacted the College because they are willing to under- take locum consultant work on a short-term basis.

If any retired member is interested in this type of work, could they write to the Secretary, enclosing a brief curriculum vitae, together with some indication of the geographical area where they would be willing to work. It would also be helpful to know the length of locums which they would be prepared to fill.

\title{
Computers in Psychiatry Special Interest Group
}

The CIPG (Computers in Psychiatry Special Interest Group of the Royal College of Psychiatrists) are holding their Annual Conference and AGM on 14 and 15 October 1994 at the Viking Hotel York. The title of the conference is 'Registering the Risk in IT". This year's special theme will be the use of IT in the implementation of the care programme approach and supervision registers. There are arguments for and against using computers in such cases and two of the speakers will be leading a debate on this subject. There will also be demonstrations of information systems. For further details, please write to Mrs Jean Wales at the College.

\section{Obituaries} Winifred Mary Burbury, formerly Senior Lecturer
in Child Psychiatry, Leeds.

Dr Burbury was born at Criggleston, near Wakefield, Yorkshire on 21 April 1897. She was educated at Wakefield High School and Harrogate College from where she proceeded to Newnham College, Cambridge and obtained a first class honours degree in History. Thereafter. she taught for eight years, during which time she became increasingly concerned about children with emotional problems.

Mary set about equipping herself to help this group, taking her first MB BS while continuing to teach in the evenings. She proceeded to a second MB BS at London King's Strand. Her clinical training was undertaken in Leeds, from where she graduated in 1932. After completing several house appointments and gaining the DPM (1934), she obtained a Commonwealth
Scholarship in Child Psychiatry Guidance Training.

Mary trained at the Tavistock Clinic while working part-time as a school medical officer in London. In 1937, she became consultant psychiatrist with Manchester Education Committee and subsequently consultant psychiatrist at both Salford Royal and the Royal Manchester Children's Hospitals. She was instrumental in establishing the only training centre outside London for the instruction of psychiatrists, psychologists and psychiatric social workers at that time.

In 1951, Mary became a consultant psychiatrist with the North East Metropolitan Region and in 1952 moved to Leeds where she had, by then, obtained a senior lectureship in child psychiatry, a post as a consultant psychiatrist to Leeds General Infirmary and acted as consultant adviser to Leeds Regional Hospital Board. In 1960 she 